\title{
Fabrication of surveyed crown and frameworks for removable partial dentures using electronic surveying
}

\author{
Ji-Young Park, Geun-Won Jang, Yu-Ri Heo, and Mee-Kyoung Son* \\ Department of Prothodontics, School of Dentistry, Chosun University, Gwangju 61452, Republic of Korea \\ (Received Feb 1, 2017; Accepted Feb 20, 2017)
}

\begin{abstract}
$\mathrm{CAD} / \mathrm{CAM}$ technology is increasingly being used for the fabrication of various prostheses. Digitized attempts are also underway for both removable partial dentures as well as fixed partial dentures. Conventional methods to fabricate removable partial denture require innumerable laboratory procedures, such as impression, surveying, blockout, making fire model, and wax-up. In this paper, we demonstrate the process using electronic surveying and blockout in Sensable's intellifit ${ }^{\mathrm{TM}}$ Digital restoration system, and zirconia surveyed crown and framework fabrication through the digital process. The clinical application of digital systems in the dental field is expected to increase with the advancement and development of technology in the near future.
\end{abstract}

KEY WORDS: Computer-aided design (CAD) and computer-aided manufacturing system (CAM), Electronic surveying, Removable partial dentures

\section{서 론}

치과 $\mathrm{CAD} / \mathrm{CAM}($ Computer-aided design and computeraided manufacturing system) 기술과 구강 스캐너의 발전으 로 고정성 보철물 제작 과정의 디지털화는 빠른 속도로 응 용, 발전되어가고 있으나, 가철성 보철물 제작에서는 기술 의 적용이 어려운 상태이다. 현재 가철성 보철물의 제작에 있어 디지털화의 제한을 야기하는 가장 큰 이유는 구강 스 캐너로 근육의 움직임이 반영된 기능인상을 채득할 수 없 기 때문이다. 일반적으로 가철성 보철물은 현재까지는 인 상채득을 통해 주모형이나 내화모형을 만들어서 제작되고 있다[1].

일반적으로 가철성 국소의치는 인상, 써베잉, 블록아웃, 내화모형 제작, 왁스업, 주조 등의 복잡한 과정을 거쳐 framework가 제작이 된다. 만약 지대치의 써베이드 크라 운이 필요한 경우에는 국소 의치 제작 전 고정성 보철물 의 제작이 선행되어야 하므로 기공 과정이 더 길어지고,

*Corresponding author: Mee-Kyoung Son

Department of Prosthodontics, School of Dentistry, Chosun University, 309 Pilmun-daero, Dong-gu, Gwangju 61452, Republic of Korea Tel.: +82-62-220-3820, Fax: +82-62-227-7811

E-mail: son0513@chosun.ac.kr
환자의 내원 횟수 또한 증가하게 된다. 이러한 과정들은 많은 재료와 시간이 필요하며, 각 과정을 거치며 오차가 발생할 가능성이 있으며, 치과의사나 기공사의 숙련도에 영향을 받을 수 있다.

이러한 수조작으로 인한 기공제작의 단점으로 인해, 국 소의치에서도 디지털 기술의 도입이 시도되고 있으나, 앞 서 언급한 조직부 기능인상 채득의 한계로 인해 전체 제 작과정을 디지털화하지는 못하고 기존의 아날로그 방법과 디지털방법이 병행되고 있다. 국소의치 디지털 제작방법 에 대해 2004년 영국 웨일즈 치과대학병원의 Williams 등[2] 이 전자 서베잉과 국소의치 제작의 디지털화에 대해 처음 소개하였으며, 최근 Intellifit ${ }^{\mathrm{TM}}$ (Sensable ${ }^{\circledR}$, Wilmington, USA) 의 Digital restoration system을 사용하고 있다. 기능인상을 채득하여 제작한 모델을 모델스캐너로 스캔한 후 디자인 과 제작 과정을 거친다. 스캔한 파일은 면으로 안과 밖이 구분되는 stereolithography(STL) 파일로 저장되며, 삼각형 의 기본단위인 폴리곤이 크기가 작고 많을수록 높은 해상 도를 갖게 되며, 삼각형이 위를 향하는지 아래를 향하는지 에 따라 최대 풍융부의 상방, 하방이 나뉘어 전자 써베잉 이 가능하게 된다[3]. 디자인 과정에는 $\mathrm{CAD}$ 디자인용 FreeForm ${ }^{\circledR}$ (SensAble Technologies, Inc., Woburn, MA) 소 프트웨어와 입력 도구로 촉감(Haptic)을 재현하는 phantom device가 사용된다(Fig. 1). 


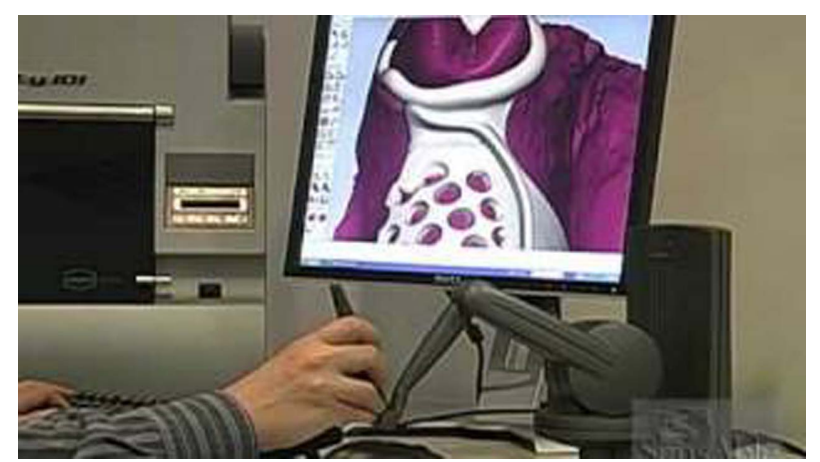

Fig. 1. Freeform software and haptic phantom device.

Haptic interface(Phantom Desktop haptic interface; Sensable ${ }^{\circledR}$, Wilmington,USA)는 포스드 피드백(Forced Feedback)효과 로 모델의 삼차원적 형태를 촉각으로 느낄 수 있어 디자 인 작업을 실제와 유사하게 재현할 수 있게 한다[4]. FreeForm 소프트 웨어의 장점 중 하나는 빠르고 정확한 전자 서베잉으로 국소의치의 삽입철거로를 결정하면, 모 형의 경사도에 따라 언더컷의 위치와 양이 나타나, 언더컷 의 정량적 평가가 가능하다는 것이다. 또한 한 화면 상에 서 동시에 반대쪽 면도 볼 수 있어 입체적 분석을 쉽게 한 다(Fig. 2). 써베잉 모형은 자동으로 블록 아웃이 되며 이 후 라이브러리에 미리 저장된 주연결장치 아이콘을 'dragged and dropped' 하여 framework를 디자인한다[5]. CAD를 이 용한 디자인은 wax의 연화와 경화과정을 거치지 않으므로 재료의 균일한 두께 뿐만 아니라, 균질한 물성을 얻을 수

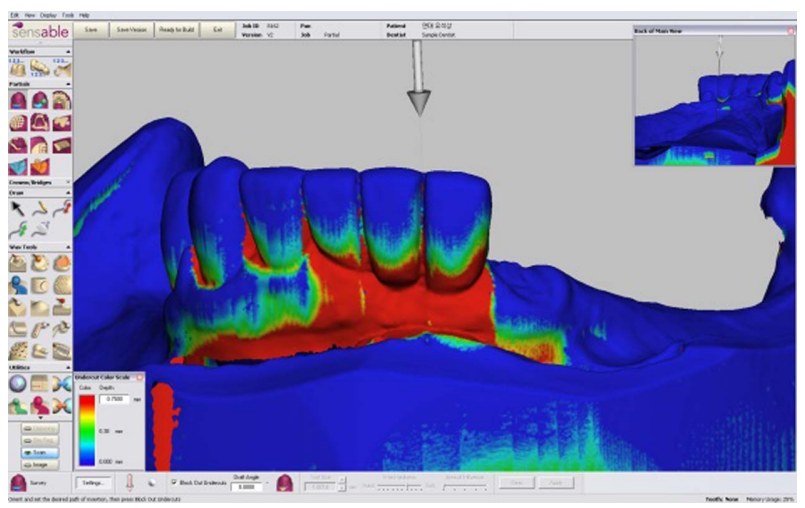

Fig. 2. Measuring undercut. Check opposite side of model at the same.

있다. 제작과정은 3D 프린터로 희생 패턴(sacrificial pattern) 이라 불리는 Resin framework을 출력하여 이를 매몰, 소환 해 금속 구조물로 만든다[3,6]. $3 \mathrm{D}$ 프린터는 방식과 사용 재료에 따라 다양한 종류가 개발 및 보급되고 있다. 본 증 례를 위해서 사용된 치과용 3D 프린터로는 powder bed에 결합제로 ink를 분사하는 inkjet printing 방식의 프린터(3D system DP3000)을 사용했으며, 한번에 대량생산이 가능하 여 경제적인 장점이 있다[7].

본 증례 보고에서는 두 명의 환자에게 Intellifit 시스템 을 이용한 디지털 방식으로 고정성 보철물인 써베이드 크 라운과 가철성 국소의치를 동시에 제작하여 만족할만한 결과를 얻었기에 보고하고자 한다.
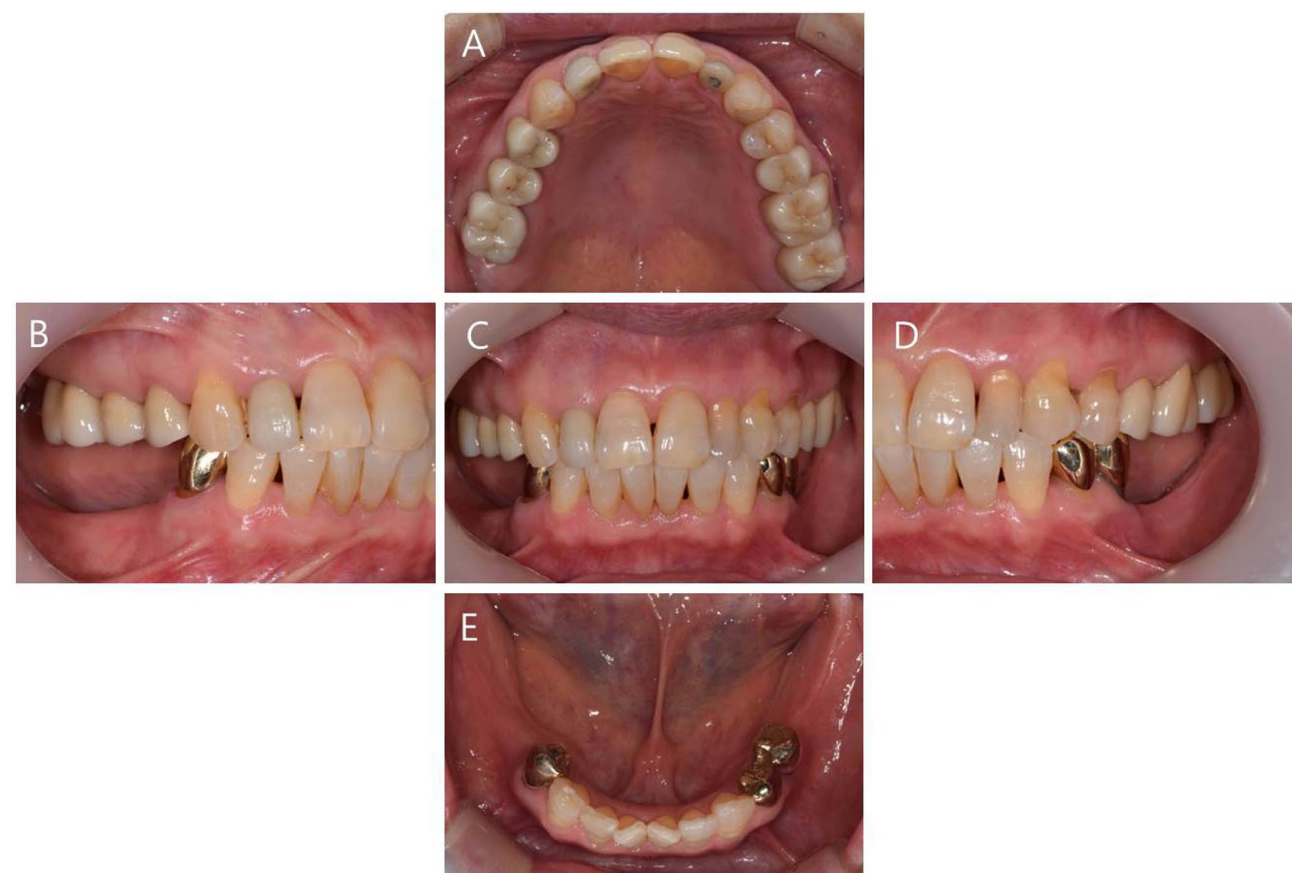

Fig. 3. Pre-treatment intraoral view. (A)Occlusal view of maxilla, (B)lateral view (right side), (C) Frontal view, (D)lateral view (left side), (E)Occlusal view of mandible 


\section{증례보고}

\section{증례 1}

첫 번째 증례는 62 세 여자 환자로 현재 사용하고 있는 의치의 불편감과 치아 통증을 주소로 조선대학교 치과병 원 보철과에 내원하였다(Fig. 3).

이차 우식이 있는 \#35는 발거하고, \#33,34,43,44 치아를 보철 수복하여 양측성 후방연장 국소의치를 제작하기로 계획하였다. 개인 트레이를 제작하고 기능인상 채득을 통 해 지대치와 조직부를 one-step으로 채득하였다. 주모형 완성 후 악간관계를 채득하고, 써베이드 크라운 제작을 위 한 색상을 선택하였다. 주모형 및 다이작업을 위한 이차모 형을 스캔하여 그 데이터를 국소의치 디자인 도구가 특화 된 소프트웨어인 FreeForm ${ }^{\mathbb{B}}$ (SensAble Technologies, Inc., Woburn, MA)으로 불러와 전자 써베잉을 통해 삽입철거로 를 결정하고 교합 관계에 맞춰 크라운을 디자인하였다 (Fig. 4).

크라운이 디자인 된 주모형의 파일을 불러와 의치의 삽 입 철거로를 설정하면 언더컷의 양이 color code로 표시된
다. 언더컷의 양이 클수록 붉은색으로 표시되며, 색에 의 한 구분뿐만 아니라 정량적인 측정도 가능하다(Fig. 5A). 이 환자의 경우 최후방 지대치의 써베잉 라인이 RPA 클 래스프 디자인에 적절하지 않아 크라운의 외형을 수정하 여 써베잉 라인을 다시 확인 하였다(Fig. 5B). 그 후 블록 아웃 도구를 이용해 언더컷 하방을 자동 블록 아웃 시행 하였다(Fig. 5C).

주연결장치와 레진의치상이 위치할 부분에 relief를 시행 한 후, 주연결장치, 부연결장치, 레스트, saddle, 클라스프, 피니싱 라인을 디자인한다. 3D 프린터(Projet-DP 3000, 3D Systems, Rock Hill, SC, USA)를 통해 레진 패턴을 출 력한 후 주모형에서 적합도를 확인한 후, 통상적인 방법으 로 매몰, 주조하여 framework를 완성하였으며, 이를 다시 주모형에 적합시켜 적합도를 확인하였다(Fig. 6). 이 환자 의 경우, 기공사와 디자인에 대한 상호 의견 교류 없이 보 철물을 완성하였는데 보철물의 주모형 상 적합도는 양호 하였지만, 국소의치 디자인의 원칙에 어긋나는 여러가지 문제들이 발견되었다. 레스트와 부연결장치 연결부가 예 각이 아닌 둔각을 이루며, 주연결장치와 부연결장치 연결 부가 직각을 이루지 않고, 부연결 장치간 거리가 부족하거
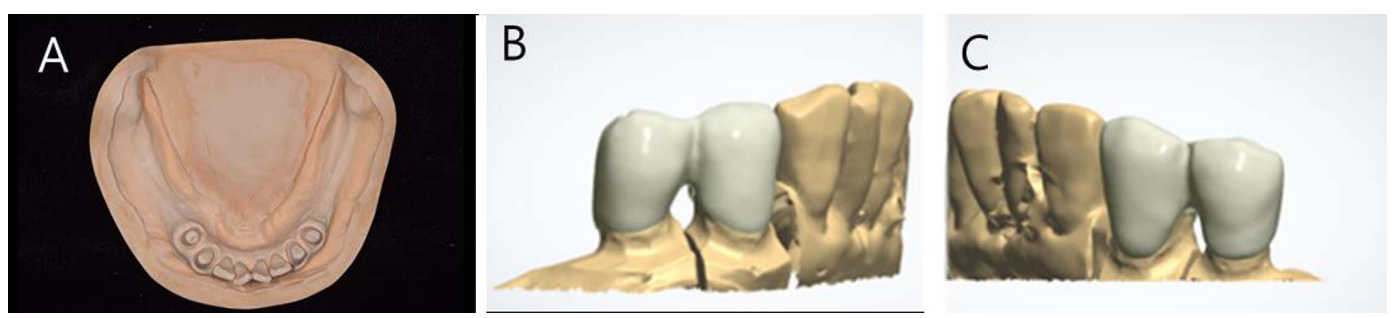

Fig. 4. (A) Master cast. Design of surveyed crown (B) Right side view (C) Left side view
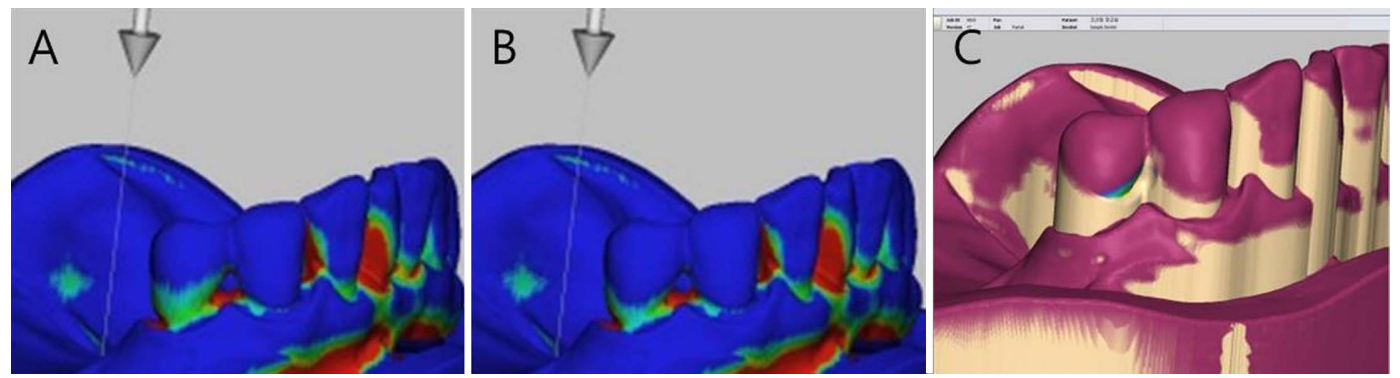

Fig. 5. (A) Initial electronic surveying (B) Final electronic surveying (C) Block-out below undercut
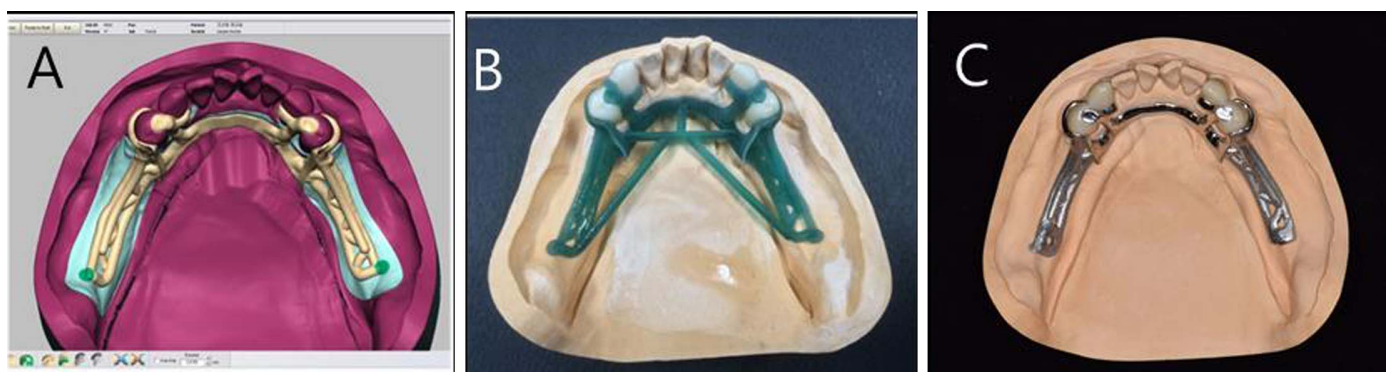

Fig. 6. (A) Finishing of framework design (B) Resin pattern (C) Finishing of framework 


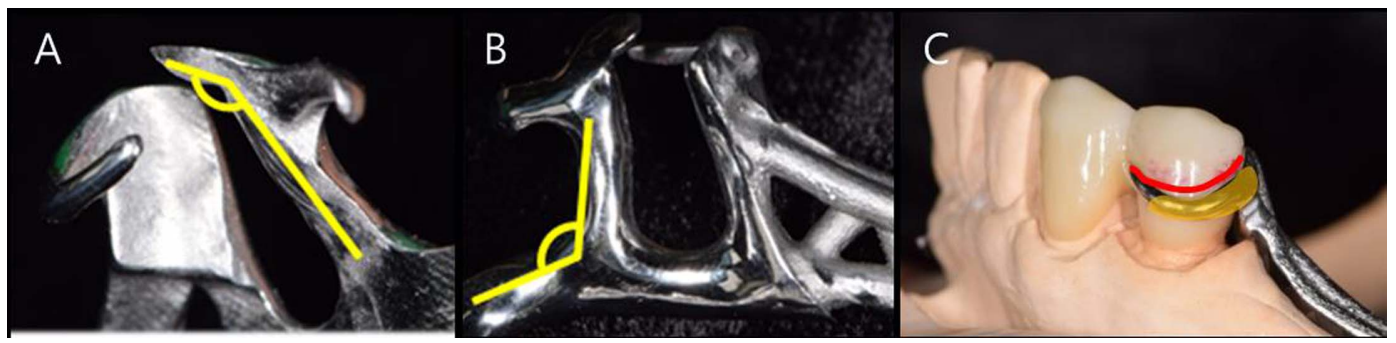

Fig. 7. Problems of framework design without discussion with dentist. (A) Angle between rest and minor connector was over 90, (B) Minor connector was not connected to major connector vertically, (C) Rigid part of clasp positioned below survery line

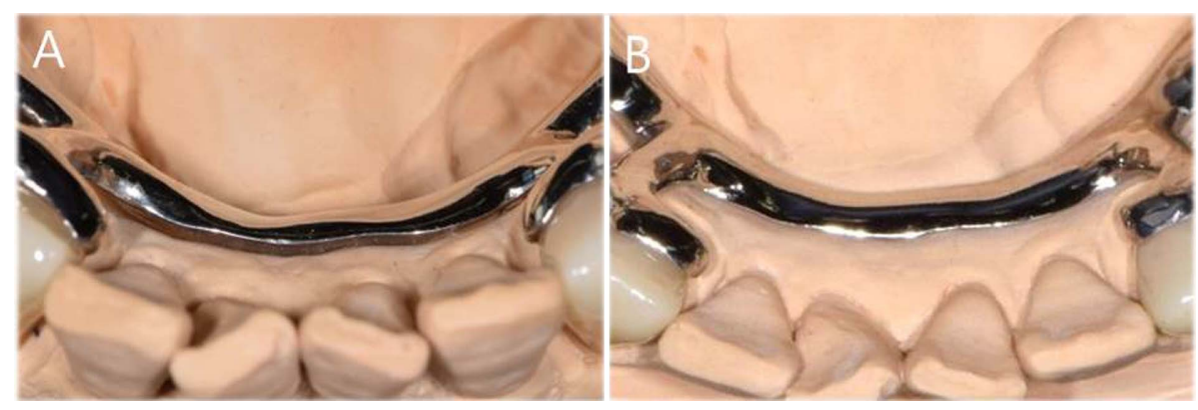

Fig. 8. (A) Excessive space under lingual bar, (B) Proper space after remaking framework.

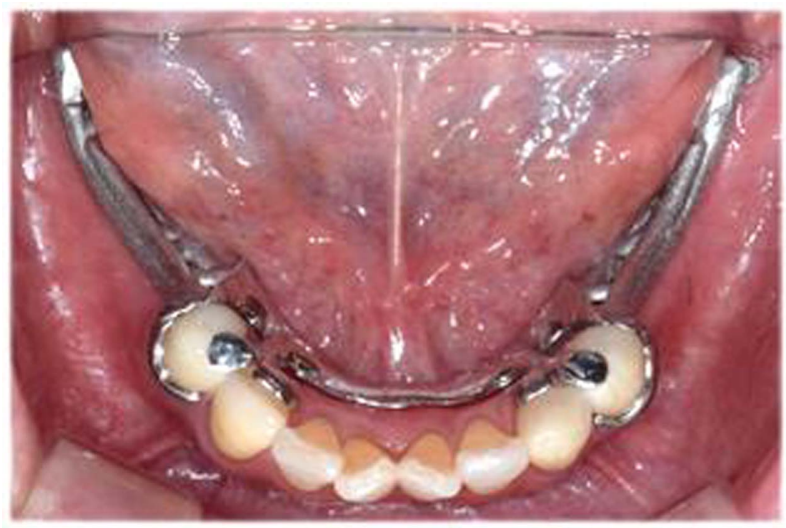

Fig. 9. Framework try in.

나, 클라스프의 견고한 부위가 써베잉 라인 하방에 위치하 게 설계되어 있었다(Fig. 7). 또한 CAD 상에서 주연결장 치 하방에 32 게이지 relief를 시행하여 framework를 제작 하였는데, 조직면과 주연결장치간에 너무 과도한 간극이 관찰되었다(Fig. 8). 따라서 relief를 하지 않고, 국소의치 설계 원칙에 적합한 디자인으로 수정하여 framework를 재
제작 하였다.

제작된 보철물을 환자의 구강 내에 시적 하였을 때 크 라운의 색상, 변연적합도, 인접면 접촉 상태가 양호했으며, framework를 시적 했을 때도 모형 상에서와 동일한 적합 상태를 보여주었다(Fig. 9). 그 후 악간관계의 채득, 납의 치 제작, 의치 온성 등의 과정을 거쳐 최종 의치를 장착하 였다(Fig. 10).

\section{증례 2}

73세 남자 환자가 이가 흔들려서 제대로 음식을 씹을 수 없다는 주소로 내원하였다. 구강 검사 결과 상악의 잔존 치근과 하악 치아의 심한 치주염이 관찰되었다(Fig. 11).

예후 불량한 \#24,25,41를 발거하고, \#12,33,44,45 치아를 전장관 수복하여 상하악 후방 연장 국소의치를 제작하기 로 하였다. 지대치와 조직부 인상채득하여 주모형을 완성 하였고 악간관계 기록 후, 치아의 색상을 선택하였다. 써 베이드 크라운을 디자인하고 전자 써베잉 및 블록 아웃을 시행하였다(Fig. 12 and 13). 상악의 경우 주모형의 적합을 위해 스캔하기 전에 모형에 beading line을 미리 형성해 주
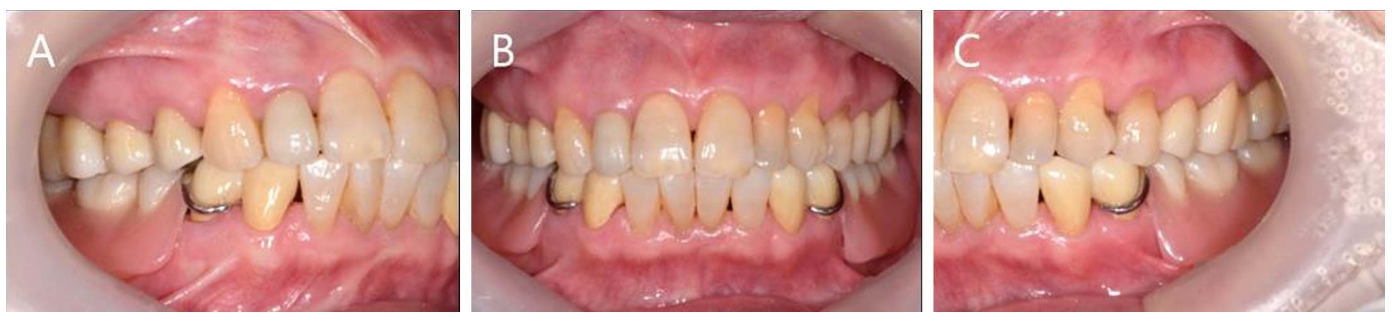

Fig. 10. Completed removable partial denture. (A) Right side, (B) Frontal, (C) Left side 


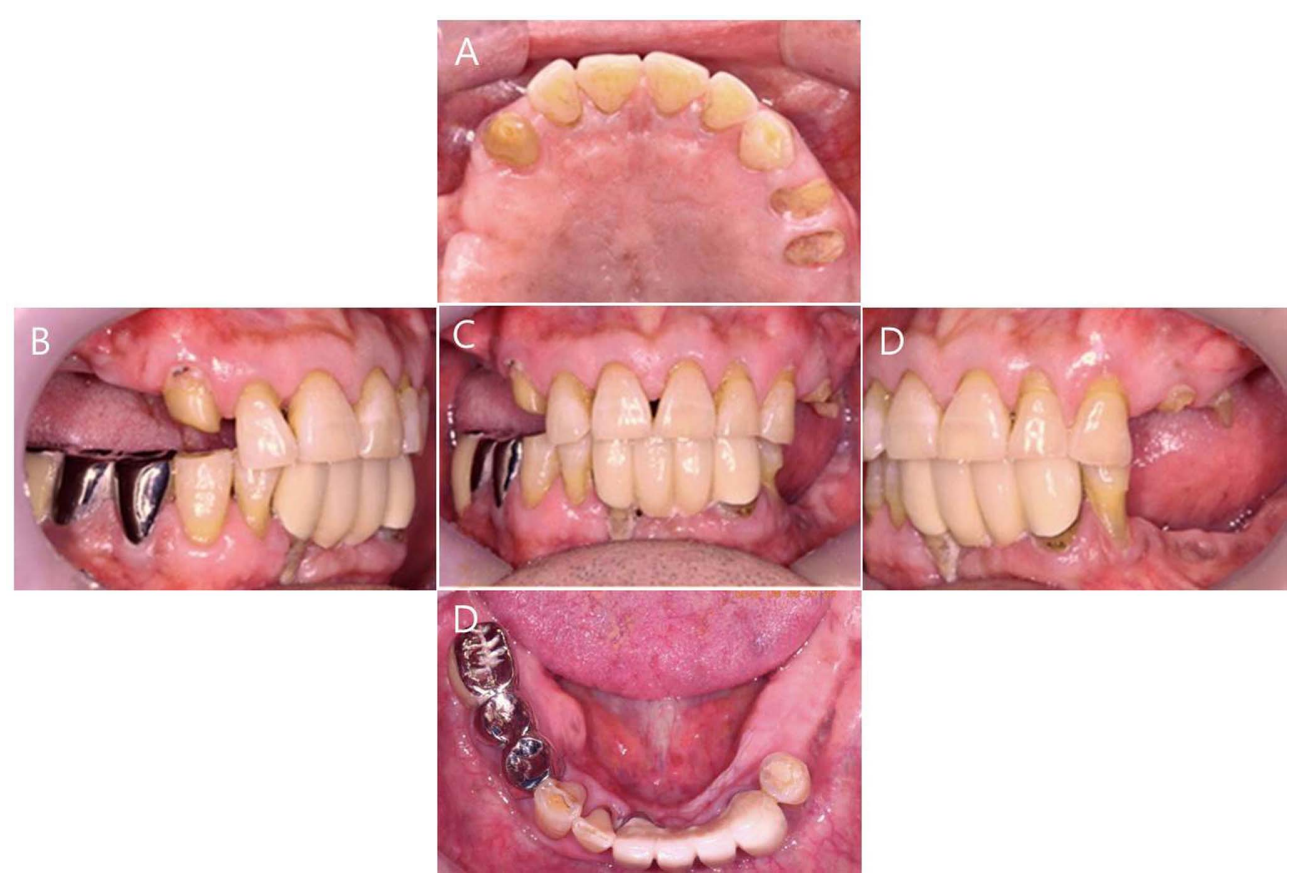

Fig. 11. Pre-treatment intraoral view. (A) Occlusal view of maxilla (B) Lateral view (right side), (C) Frontal view, (D) Lateral view (left side), (E) Occlusal view of mandible
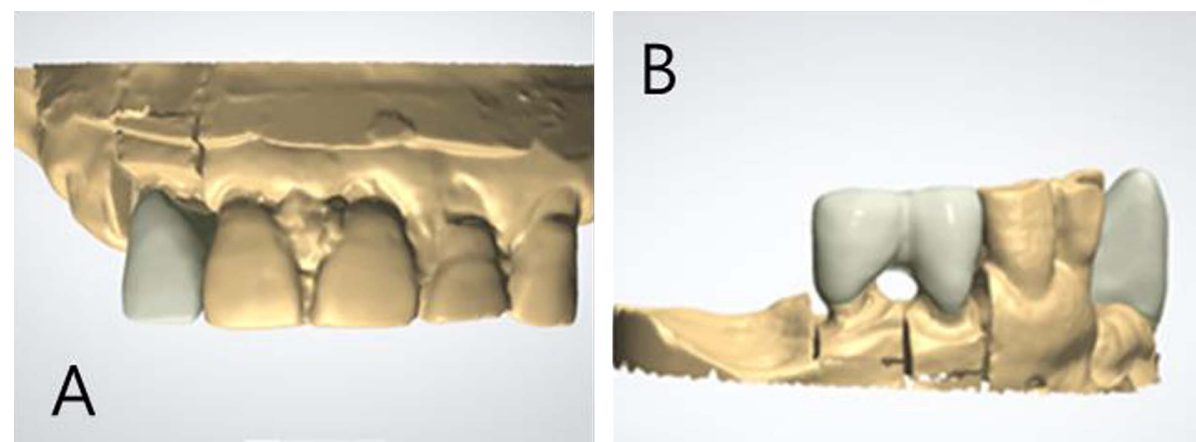

Fig. 12. Design of surveyed crown. (A) Frontal view of maxilla, (B) Lateral view of mandible
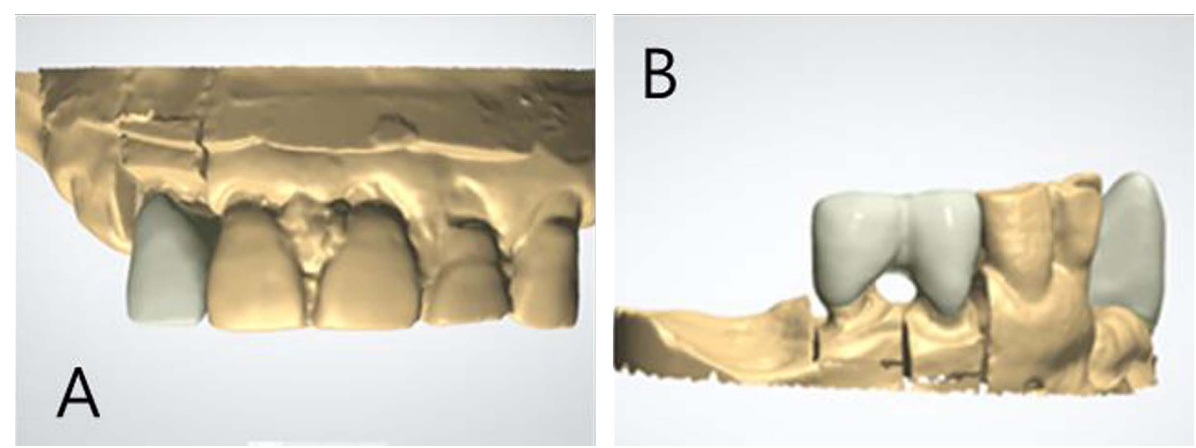

Fig. 13. (A) Electronic surveying, (B) Block out below undercut

었다. saddle, 레스트, 주연결장치, 클라스프, 피니싱라인 순으로 디자인 하였다(Fig. 14). 레진 패턴을 소환 및 주조 하여 framework를 주모형에 적합 시 양호한 적합성을 나
타내었다(Fig. 15). 구강 내 시적 시에도 크라운과 금속구 조물의 적합도는 양호하여(Fig. 16), 통상적인 방법으로 의 치 제작을 시행하였다(Fig. 17). 
Ji-Young Park et al.
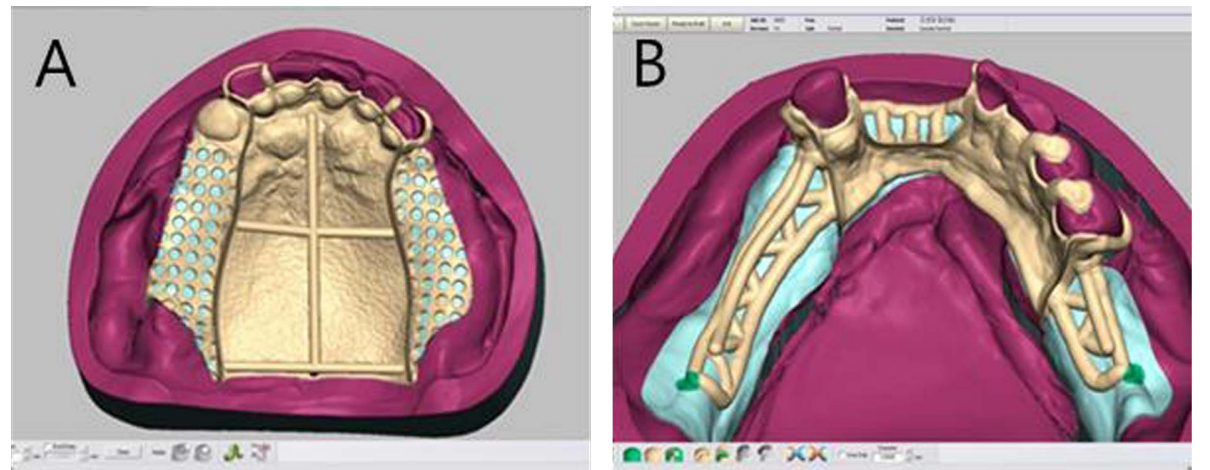

Fig. 14. Design of framework. (A) Upper, (B) Lower
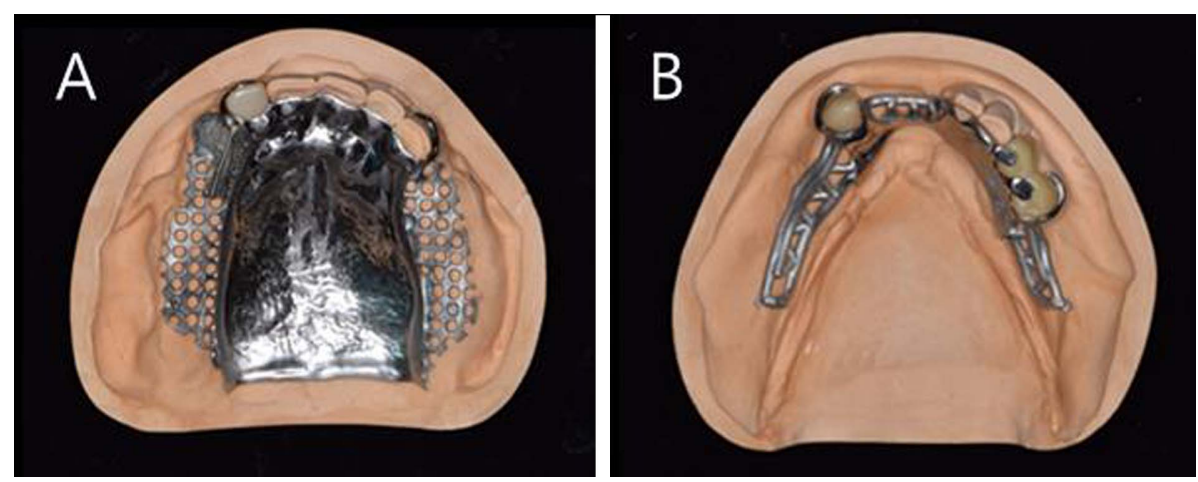

Fig. 15. Metal framework. (A) Upper, (B) Lower
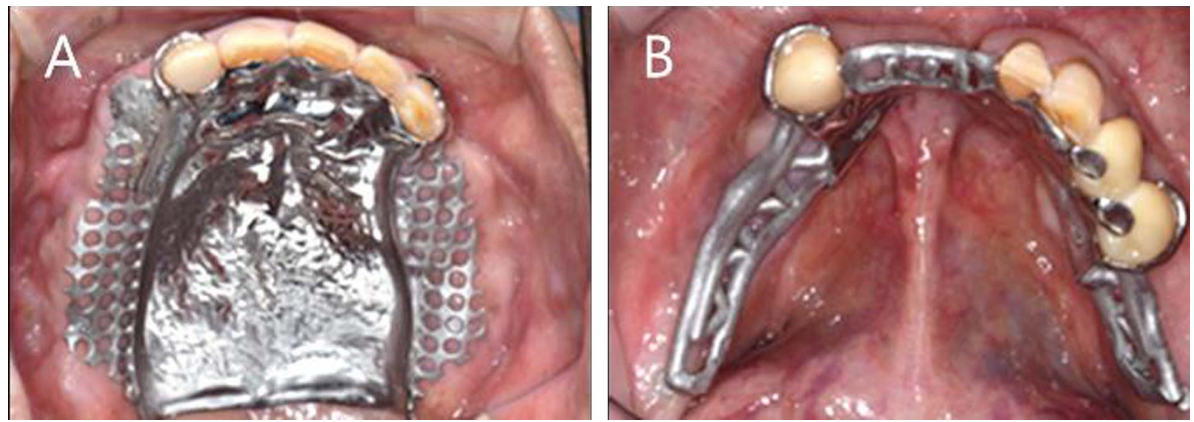

Fig. 16. Framework try in (A) Upper, (B) Lower
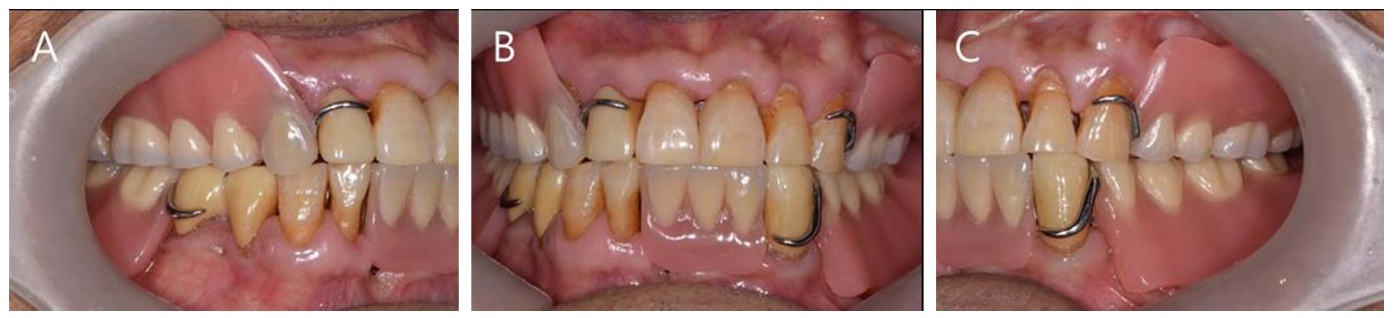

Fig. 17. Completed removable partial denture. (A) Right side, (B) Frontal (C) Left side

\section{고 찰}

Intellifit 시스템을 이용한 국소의치 제작은 모델 스캔에 10 분, 프로그램 디자인 작업은 약 15 분 정도 소요되며, 그
후 레진 패턴 제작에 8 시간이 소요된다. 숙련자의 경우 매 몰 전까지 작업이 필요한 과정은 총 25 분이며 기존 아날 로그 방식으로 써베잉, 블록 아웃, 내화모형 제작, wax 패 턴 제작까지 걸리는 시간을 크게 단축시킬 수 있다. 또한 한번에 국소의치 framework를 약 15 개까지 만들 수 있어 
경제적이다.

국소의치가 분실되거나 파절되었을 경우, 재제작하기 위해서는 복잡한 기공과정을 다시 거쳐야하며, 수작업으 로 진행되므로 완전히 동일한 framework의 제작은 불가능 하다고 볼 수 있다. 그러나 CAD-CAM으로 제작한 국소의 치의 경우 디자인 파일의 저장이 가능하여 동일한 framework를 제작 할 수 있다.

$\mathrm{CAD}$ 프로그램으로 써베이드 크라운 디자인은 가능하지 만 크라운을 금속 도재관으로 제작하는 경우 도재를 수작 업으로 축성하기 때문에 디자인한 것과 똑같은 언더컷을 부여할 수 없는 취약점이 있다. 하지만 STL 파일로 밀링 이 가능한 지르코니아를 이용하는 경우에는 지대치와 조 직의 기능운동이 인기된 주모형의 스캔을 통해 써베이드 크라운과 금속 구조물을 동시에 디자인하고 제작하는 것 이 가능하여 framework와 지르코니아의 적합도를 높일 수 있다. 또한 기존의 가철성 국소의치를 사용하고 있는 환자 에서 써베이드 크라운이 파절되고 framework의 재제작이 어려운 상황일 경우에도, 지르코니아 크라운을 사용하면, 도재를 축성하는 금속도재관보다 기공과정을 줄이고 framework와 적합도를 높일 수 있는 장점도 있다[8]. 지르 코니아를 국소의치 지대치로 사용하는 것에 대해 일부 논 문에서는 적합성이나 예후에 문제가 없다고 보고하고 있 으나[9], 코발트-크롬 합금과의 마모도 평가, 지르코니아 써베이드 크라운 표면이 장기간의 framework탈착으로 손 상되었을 경우의 강도 변화 등 장기적인 예후 관찰이 필 요하다.

첫 번째 증례에서 조직면과 주연결장치간에 너무 과도 한 간극이 관찰되어 릴리프를 시행하지 않고 다시 제작하 여 적절한 적합도를 얻었다. Park 등[10]은 디지털방식으 로 제작한 framework를 실제 환자 구강 내에 장착하여 측 정한 간극이 $\mathrm{CAD}$ 프로그램 상의 framework와 모델과의 간극을 파일 상에서 분석한 수치보다 $105 \mu \mathrm{m}$ 더 크다고 보고했다. 이러한 차이가 스캔의 부정확성인지, 레진패턴 의 변형이나 매몰과 주조 과정에서 발생한 오차인지 판별하 기 위해서는 추가적인 연구가 필요하다. 코발트-크롬 금속 파우더를 얇게 뿌린 다음 형상을 만들 지점을 레이저로 소 결하는 Selective laser melting(SLM) 방식으로 framework를 만든다면 매몰과 주조 과정상의 오차를 일부 줄일 수 있 을 것으로 사료된다. 그러나 고가의 장비가 필요하여 아직 의치의 디지털화가 일반적이지 않은 국내에서 보급되기는 힘든 상황이다[10-12].

국소 의치 설계를 기공사에 의존하는 경우에 국소 의치 설계의 원칙에 맞지 않게 설계되는 경우가 있다. 따라서 기공사에게만 의존하지 않고, 디지털 제작과정에서 치과의 사와의 협업이 필수적으로 요구된다. 여기서 제작 파일을 실 시간으로 온라인상으로 쉽게 공유하여 의견을 나눌 수 있다
는 점이 디지털 제작과정의 장점이라고 볼 수 있다.

아직까지 인상부터 주조까지의 전 과정을 디지털화 하 지는 못하며, 디지털 인상 채득의 오차, 부족한 적합도와 가격대비 기계의 짧은 수명 등의 해결해야 할 문제들이 있 지만 앞서 언급한 장점들과 환자의 만족도 측면에서 국소 의치 디지털화의 충분한 이점은 있다.

\section{결 론}

Intellifit 시스템을 사용하여 디지털 방식으로 국소의치 를 제작한 두 증례에서 크라운과 framework의 적합도, 장 착 후 안정성과 착탈 시의 저항감 및 유지력은 양호하였 고, 환자들도 심미적, 기능적으로 만족스러워 하였다. 디지 털 제작의 보완 기술들이 앞으로 더욱 개발되고, 합리적인 가격대가 형성된다면 가까운 미래에 국소의치 제작의 디 지털화가 일반화될 수 있을 것이라 생각된다.

\section{감사의 글}

이 논문은 2014년도 조선대학교 학술연구비의 지원을 받아 연구되었음.

\section{Conflict of Interest}

The authors declare that they have no competing interests.

\section{ORCID}

Ji-Young Park 0000-0001-9169-851X

Geun-Won Jang 0000-0003-2948-2472

Yu-Ri Heo 0000-0002-1806-3822

Mee-Kyoung Son 0000-0001-9225-1744

\section{References}

1. Kim RW, Jang GW, Heo YR, Son MK. Understaning and Application of Digital Impression in Dentistry. Korean J Dent Mater 2014;41:253-261. doi: 10.14815/ kjdm.2014.41.4.253.

2. Williams RJ, Bibb R, Rafilk T. A technique for fabrication patterns for removable partial denture frameworks using digitized casts and electronic surveying. J Prosthet 
Dent 2004;91:85-88. doi: http://dx.doi.org/10.1016/j.prosdent.2003.10.002.

3. Hong YS, Park EJ, Kim SK, Koak JY, Heo SJ, Park JM. Surveyed restoration and RPD framework design utilizing electronic surveying. J Korean Acad Prosthodont 2011; 49:354-361. doi: https://doi.org/10.4047/jkap.2011.49.4.354.

4. Williams RJ, Bibb R, Eggbeer D, Collis J. Use of CAD/ CAM technology to fabricate a removable partial denture framework. J Prosthet Dent 2006;96:96-99. doi: http://dx.doi.org/10.1016/j.prosdent.2006.05.029.

5. Eggbeer D, Bibb R, Williams R. The computer-aided design and rapid prototyping fabrication of removable partial denture frameworks. Proc Inst Mech Eng $\mathrm{H}$ 2005;219:195-202.

6. Bibb RJ, Eggbeer D, Williams RJ, Woodward A. Trial fitting of a remobable partial denture framework made using computer-aided design and rapid prototyping techniques. Proc Inst Mech Eng H 2006;220:793-797.

7. van Noort R. The future of dental devices is digital. Dental Materials 2012;28:3-12. doi: http://dx.doi.org/10.1016/j. dental.2011.10.014.

8. Paek J, Noh K, Pae A, Lee H, Kim HS. Fabrication of a
CAD/CAM monolithic zirconia crown to fit an existing partial removable dental prosthesis. J Adv Prosthodont 2016;8:329-332. doi: https://doi.org/10.4047/jap.2016.8. 4.329 .

9. Lee SK, Yang HS, Park SW, Yun KD, Lim HP. An alternative method to convert fractured metal ceramic surveyed crown into an complete contour zirconia surveyed crown using CAD-CAM technology under anticancer treatments: a clinical report. J Dent Rehabil Appl Sci 2015;31:45-49. doi: https://doi.org/10.14368/jdras.2015.31. 1.45 .

10. Park JM, Hong YS, Park EJ, Kim SK, Koak JY, Heo SJ. Study on the accuracy of digital removable partial denture and the comparison with the CAD model: A Pilot Study. Biomater Res 2012;16:102-107.

11. Pham DT, Gault RS. A comparison of rapid prototyping technologies. Int J Mach Tool Manuf 1998;38:12571287.

12. Yadroitsev I, Bertrand P, Smurov I. Parametric analysis of the selective laser melting process. Appl Surf Sci 2007;253:8064-8069. doi: http://dx.doi.org/10.1016/ j.apsusc.2007.02.088. 